\title{
Water erosion response to rainfall and land use in different drought-level years in a loess hilly area of China
}

\author{
Wei Wei ${ }^{a}$, Liding Chen ${ }^{\mathrm{a}, *}$, Bojie $\mathrm{Fu}^{\mathrm{a}}$, Jin Chen ${ }^{\mathrm{b}}$ \\ a State Key Laboratory of Urban and Regional Ecology, Research Center for Eco-environmental Sciences, Chinese Academy of Sciences, Beijing 100085, China \\ ${ }^{\mathrm{b}}$ Dingxi Institute of Soil and Water Conservation, Dingxi, Gansu 743000, China
}

\section{A R T I C L E I N F O}

Article history:

Received 5 February 2009

Received in revised form 27 August 2009

Accepted 9 January 2010

\section{Keywords:}

Rainfall

Variation

Land use

Water erosion

Loess Plateau

Drought-level year

\begin{abstract}
A B S T R A C T
Due to rainfall variation and poor land cover, water erosion in the loess hilly area is severe and experiences high temporal fluctuations, which increase the difficulties of erosion quantification, prediction and control. In this study, 15 runoff plots were implemented in Dingxi, a typical loess hilly area of Gansu Province since 1986. Three typical years representing WY (wet year), NY (normal year) and DY (drought year) were firstly filtered based on the consecutive rainfall-erosion data and an aridity index. Then, water erosion dynamics involving five land uses (cropland, alfalfa, scrubland, woodland and grassland) in the three typical years were analyzed. The following results were found. Firstly, the most severe annual erosion rates did not appear in WY, but in DY. Moreover, the rates in DY were far higher than those in NY and WY. Secondly, although total rain depth and number of events were in the order of $W Y>N Y>D Y$, mean maximal intensity of erosive rainfall however, was in the order of DY $>$ NY $>$ WY. This finding is important for erosion control. Namely, we cannot judge water erosion degree just from annual rainfall. More attention should be paid to the specific rainfall variables and distributions. Thirdly, different land uses played an important role with sea buckthorn reducing water erosion in contrast to spring wheat cultivated on steep slopes. Lastly, regardless of different drought-level years, only a few number of events with high intensities were responsible for the majority of annual soil and water loss.
\end{abstract}

(c) 2010 Elsevier B.V. All rights reserved.

\section{Introduction}

Soil erosion caused by water is one of the most severe erosion forms across the globe and has attracted high attention during the past, mainly due to its on-site and off-site destructive effects ( $\mathrm{Fu}$, 1989; Römkens et al., 2001; de Lima et al., 2003; Davision et al., 2005; Chen et al., 2007a; Casalí et al., 2008; Wei et al., 2009). Abundant studies have uncovered that persistent severe erosion can deteriorate soil conditions, reduce water holding capacity, decrease aggregate stability and soil biodiversity, and bring serious ecological crisis such as eutrophication, non-point pollution and eventually land degradation (Bosch and Hewlett, 1982; Gafur et al., 2003; Singer and Shainberg, 2004; Ulén and Kalisky, 2005; Jin et al., 2008). For example, a study in America indicated that the crop yields would be reduced by 2 to $4 \%$ if current water erosion rates continue for the next 10 decades (Trimble and Crosson, 2000). New reports claim that there is a clear relation between erosion and changes in carbon cycle and precipitation (Weltzin et al., 2003; Nearing et al., 2005). Measurements at the field scale indicate that the soil organic carbon pool (SOCP) decreases significantly after long-term severe erosion, which

\footnotetext{
* Corresponding author. Tel.: +8610 62943840; fax: +861062849102.

E-mail addresses: weiwei@rcees.ac.cn (W. Wei), liding@rcees.ac.cn (L. Chen), bfu@rcees.ac.cn (B. Fu), gsdxchj@126.com (J. Chen).
}

in turn may release huge amounts of $\mathrm{CO}_{2}$ to the atmosphere and eventually contribute to global warming (Lal and Pimentel, 2008). Controlling severe erosion thus becomes more urgent to ensure the sustainability of our terrestrial systems facing the 21st century.

Natural processes of soil and water loss fluctuate highly between different seasons and years, and this is more significant in the fragile arid environments with sparse vegetation covers (Merz et al., 2006). These fluctuations increase the difficulties of accurate erosion measurement and prediction (Hogarth et al., 2004; Busnelli et al., 2006). Moreover, such intra- and inter-annual changes in water erosion are complex and caused by many synergistic reasons (Busnelli et al., 2006; Chen et al., 2007b). Among these factors however, the spatiotemporal variations of rainfall play a key role (Apaydin et al., 2006; Wei et al., 2007, 2009; Baigorria et al., 2007). Due to poor vegetative cover and fragile ecosystem, surface hydrological responses are even sensitive to small fluctuations of rainfall in the semiarid regions (Yair and Raz-Yassif, 2004; Wang et al., 2005; Nearing et al., 2005; Leblance et al., 2008). Knowledge about the role of rainfall temporal variations on water erosion is thus significant for erosion control and larger-scale hydrological predictions.

Besides rainfall, land use also influences water erosion (Braud et al., 2001; Dunjó et al., 2004; Foley et al., 2008). Deforestation, cultivation of steep slopes and other strong agricultural activities have induced severe erosion and land degradation in huge areas around the 
world (Bosch and Hewlett, 1982; Gafur et al., 2003; Chen et al. 2007a). Proper land use adjustment and vegetation restoration, however, can improve the effectiveness of land cover, consolidate the heath and stability of local ecosystems, and reduce the sensitivity of soil erosion and water loss to temporal changes in rainfall (Dunjó et al., 2004; Merz et al., 2006; Eugenia et al., 2007).

More notably, water erosion in the key loess hilly region of China shows a complex pattern of seasonal variability, with wide and unpredictable rainfall fluctuations from year to year (Chen et al., 2007b). There is a common sense that heavier rainfall or more annual rain causes more severe soil erosion and water loss (local questionnaire, unpublished materials). Videlicet, there is a positive relation between water erosion and rainfall depth. However, is this cognition always consistent with reality? Does the most severe water erosion always appear in the wettest year, and vice versa? Can wise land use reduce or even eliminate the temporal fluctuation of water erosion? These questions will be treated in this study.

Based on field measurement data, three typical years which represent a WY (wet year), NY (normal year) and DY (drought year) will be identified. Then, the characteristics of rainfall and corresponding water erosion responses under five land use types will be analyzed regarding: (1) water erosion dynamics in different drought-level years, (2) water erosion in relation to land use, (3) interaction between rainfall and land use regarding water erosion in different drought-level years.

\section{Study area}

The study was conducted in a typical hilly loess area named Anjiapo catchment $\left(35^{\circ} 33^{\prime}-35^{\circ} 35^{\prime} \mathrm{N}, 104^{\circ} 38^{\prime}-104^{\circ} 38^{\prime} \mathrm{E}\right)$ in Dingxi, Gansu, in the western part of the Chinese Loess Plateau. According to the water deficit index (WDI) and the aridity index (AI), this area is semiarid and dominated by warm-humid summers and cold-dry winters (Huang et al., 2005; Chen et al., 2007a, 2007b). Mean annual precipitation (from 1956 to 2006) in this region is $427 \mathrm{~mm} / \mathrm{yr}$, of which the majority (more than $80 \%$ ) falls from May to September (Wei et al., 2007). The historical record of maximum annual precipitation was $722 \mathrm{~mm}$ in 1967, and minimum record was $246 \mathrm{~mm}$ in 1982. The mean annual pan evaporation can reach $1510 \mathrm{~mm} / \mathrm{yr}$.

The soils developed from loess, which ranges in depth from 40 to $60 \mathrm{~m}$. Groundwater is not available for vegetation growth due to the deep loess. Rainfall is thus the only water resource. Deep percolation can be neglected in most cases owing to limited rainfall. Dominant soil in the region is a calcic Cambisol (FAO-UNESCO, 1974) with a clay content of $33-42 \%$, organic matter of $4-13 \mathrm{~g} / \mathrm{kg}$, and a bulk density from 1.09 to $1.36 \mathrm{~g} \mathrm{~cm}^{-3}$ within $2 \mathrm{~m}$ depth (Huang et al., 2004). Most of the natural vegetation has been converted to rain-fed farmland, causing a loss of ground cover protection. The majority of the remainders between the fields are secondary shrubs, grasses and some other artificial vegetation.

\section{Methodology}

\subsection{Materials and field treatments}

Fifteen runoff-erosion plots were collocated on a hillslope near the meteorological field station of the Dingxi Soil and Water Conservation Institute. They constitute five land use types with three replications $\left(10^{\circ}, 15^{\circ}, 20^{\circ}\right)$ at a mean slope of $26.80 \%$ in the experimental plots. (1) Cropland (Spring wheat: Triticum aestivum L. cv Leguan. Size: $10 \mathrm{~m} \times 5 \mathrm{~m}$ ): Field management was similar to that used by local farmers: the wheat was sown in April and harvested manually in late July or early August. (2) Alfalfa (Medicago sativa L. Size: $10 \mathrm{~m} \times 5 \mathrm{~m}$ ): Seeds were drilled or broadcasted in April and harvested in late July. (3) Scrubland (Sea buckthorn: Hippophea rhamnoides L. Size:
$10 \mathrm{~m} \times 10 \mathrm{~m}$ ): Saplings of sea buckthorn were planted in $1.0 \mathrm{~m}$ by $1.0 \mathrm{~m}$ spacing in March, 1986. Litter remained on the plots during the experiment. Few human disturbances existed due to the plant's high density and spiny branches. (4) Woodland (Chinese pine: Pinus tabulaeformis Carr. Size: $10 \mathrm{~m} \times 10 \mathrm{~m}$ ): Chinese pine saplings were planted in $3.0 \mathrm{~m}$ rows and $1.5 \mathrm{~m}$ columns in March, 1986, without artificial pruning and irrigation. (5) Semi-natural grassland (Size: $10 \mathrm{~m} \times 5 \mathrm{~m}$ ): This plot was left growing without any human disturbance since 1986 when cropland was abandoned, and wheatgrass (Agropyron cristatum L. Gaertn.) has now become the dominant species in the patch. It is a typical grass species in cold-dry regions. The mean annual vegetative coverage of the five land use types from 1986 to 2006 was 51\% (cropland), 54\% (alfalfa), 93\% (scrubland), $66 \%$ (woodland) and 89\% (semi-natural grassland), respectively.

\subsection{Measurements}

Daily rainfall events were recorded by two automatic pluviometers within the study area and stored by a data logger. Several key rainfall variables including amount, duration and maximum intensity in 30 min were calculated. The corresponding event runoff volume from each plot in each rainfall event was recorded simultaneously. Sediment from the fifteen plots was firstly sampled using $250 \mathrm{ml}$ bottles, then allowed to settle and separated from the water, dried in an air forced oven to constant weight at $105^{\circ} \mathrm{C}$. The data were then used to calculate the related hydrological indices representing the degrees of soil and water loss. Totally, data from 1986 to 2006 (data in 2000 and 2001 missing) were collected for further analyses.

\subsection{Aridity classification}

Climatologist use an "aridity index" (e.g. the ratio of potential evaporation to rainfall) to help classify desert (arid) or humid areas, studying drought and related hydrological processes (Western et al., 2004; Cook et al., 2007). In the study area, rainfall input was considered as the only water source and evaporation as basic water output leading to an index for different drought-level year classification.

$A I=E V / R D$

where AI, EV and RD denote aridity index, pan evaporation and rainfall depth, respectively.

\subsection{Statistical methodology}

Two indicators were selected to quantify surface runoff and soil erosion.

(1) Water loss ratio

$R R=(S R / R D) \times 100 / 100$

where RR, SR and RD refer to runoff ratio, surface runoff and rainfall depth, respectively.

(2) Erosion rate

$E R=S L / P A$

where ER, SL and PA indicate erosion rate, soil loss and area of each experimental plot, respectively.

All the data were analyzed with the software of SPSS13.0 for windows. 


\section{Results}

\subsection{Drought-level year selection}

Based on the monitored rainfall and pan evaporation data, the annual aridity indices from 1986 to 2006 (no available data in 2000 and 2001) were calculated (Fig. 1).

In all cases the potential evaporation was far higher than the annual rainfall. The mean aridity index was 2.997 (Fig. 1). We choose three typical drought-level years for further analyses. According to the yearly aridity anomalies (differences between the yearly values of aridity indices and long-term average), three typical years, 1993, 1997 and 1999, were selected to represent WY, DY and NY in this area, respectively.

\subsection{Rainfall in different drought-level years}

\subsubsection{Rainfall properties}

The depths of total rainfall and erosive rainfall from May to September in the three typical years varied highly among different years and seasons (Table 1). The total rainfall depths during the growing seasons were in the descending order of wet year $(395 \mathrm{~mm}$ in 1993) > normal year (272 $\mathrm{mm}$ in 1999) > drought year (237 $\mathrm{mm}$ in 1997). The total depths of the erosive rainfall events however, were in the order of $\mathrm{NY}>\mathrm{WY}>\mathrm{DY}$. The ratios of total rainfall amount to erosive rainfall amount from May to September were in the descending order of June $>$ August $>$ July $>$ September $>$ May, August $>$ May $>$ July $>$ June $=$ September, and July $>$ May $>$ June $>$ August $>$ September in WY (1993), DY (1997) and NY (1999), respectively. This indicates that rainfall depths varied greatly between different drought-level years.

The range, minimum and maximum values, sum and mean values, variance and coefficient of variation of rainfall depth, duration, average intensity and maximum intensity in 30 min varied among different drought-level years (Table 2).

The accumulated rainfall depth of total erosive events was highest in WY $(223 \mathrm{~mm})$, followed by NY $(191 \mathrm{~mm})$ and DY $(116 \mathrm{~mm})$. The highest values of mean rainfall amount, however, did not appear in WY but in DY, mainly due to the lower frequencies and higher depth of each rainfall event in DY. The average rain intensity and mean maximal 30-minute intensity were both highest in DY, and amounted to $0.08 \mathrm{~mm} / \mathrm{min}$ and $0.35 \mathrm{~mm} / \mathrm{min}$. The lowest values appeared in $\mathrm{NY}$ $(0.05 \mathrm{~mm} / \mathrm{min})$ and DY $(0.09 \mathrm{~mm} / \mathrm{min})$.

The range and coefficient of variation of each rainfall variable also differed among different years. For example, the range and the coefficient of variation of rainfall depth and duration descended in the order of $\mathrm{WY}>\mathrm{NY}>\mathrm{DY}$ (Table 2). The average intensity and maximal intensity, however, descended in the order of $D Y>W Y>N Y$, and $\mathrm{NY}>\mathrm{DY}>\mathrm{WY}$ respectively.

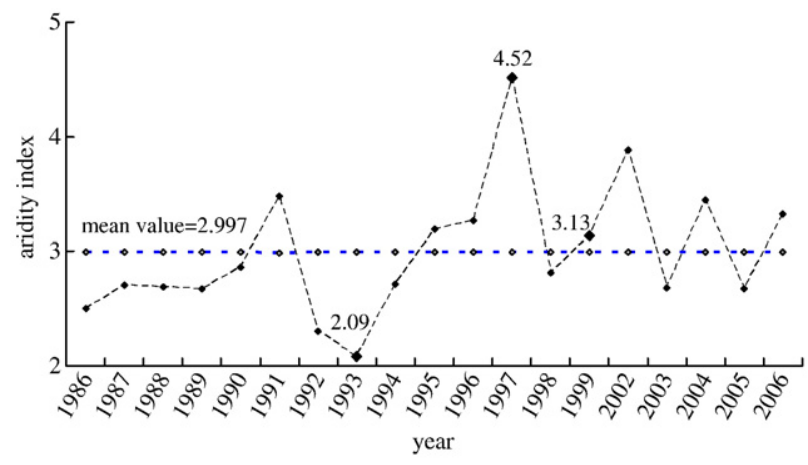

Fig. 1. Aridity index in different years.
Table 1

Characteristics of rainfall amount in different years.

\begin{tabular}{|c|c|c|c|c|c|c|c|c|c|}
\hline \multirow[t]{2}{*}{ Month } & \multicolumn{3}{|c|}{ WY (1993) } & \multicolumn{3}{|c|}{ DY (1997) } & \multicolumn{3}{|c|}{ NY (1999) } \\
\hline & TRD & ERD & Ratio & TRD & ERD & Ratio & TRD & ERD & Ratio \\
\hline May & 102.90 & 37.50 & 36.44 & 25.00 & 15.70 & 62.80 & 18.60 & 15.10 & 81.18 \\
\hline June & 62.70 & 43.60 & 69.54 & 15.30 & 0.00 & 0.00 & 77.20 & 48.00 & 62.18 \\
\hline July & 88.60 & 52.10 & 58.80 & 95.20 & 41.20 & 43.28 & 86.60 & 77.70 & 89.72 \\
\hline August & 106.00 & 71.70 & 67.64 & 67.10 & 58.70 & 87.48 & 68.90 & 39.90 & 57.91 \\
\hline September & 34.30 & 17.60 & 51.31 & 33.90 & 0.00 & 0.00 & 20.40 & 9.80 & 48.04 \\
\hline Total & 394.50 & 222.50 & 56.40 & 236.50 & 115.60 & 48.88 & 271.70 & 190.50 & 70.11 \\
\hline
\end{tabular}

Note: TRD refers to total rainfall depth (unit: $\mathrm{mm}$ ). ERD refers to erosive rainfall depth (unit: mm). Ratio denotes (ERA/TRA) 100\% (unit: \%).

\subsubsection{Rainfall numbers and frequencies}

The numbers and frequencies of rain events and erosive rain events varied greatly among different years (Fig. 2). Specifically, rain events occurred 58, 44 and 52 times in WY, DY and NY, respectively. Erosive rain events in the three typical years however, occurred 11, 5 and 15 times, respectively. Thus the frequency of erosive events was higher in DY than that in the two other years.

The two types of rain events distributed unevenly during May to September. Generally, the rain events concentrated more in the period from June to August (Fig. 2), while the erosive rain events occurred stochastically without apparent rules. For example, erosive events in 1993 experienced their highest frequencies (4 times) in August, while in 1999 the highest frequency (5 times) appeared in July. Although the in WY and NY erosive rain events occurred in June and September, no erosive rain events happened in the two months in DY.

\subsection{Water erosion in different drought-level years}

\subsubsection{Annual and seasonal water erosion rates}

Both, the highest annual runoff ratios and mean erosion rates were not measured in WY (Fig. 3), but occurred in DY, amounting to $8.2 \%$ and $3213 \mathrm{tkm}^{-2}$, respectively. These values were far higher than

Table 2

Descriptive statistics of rainfall variables in different years.

\begin{tabular}{|c|c|c|c|c|c|}
\hline Year & Statistics & $\mathrm{RD}(\mathrm{mm})$ & $D(\min )$ & A.I. $(\mathrm{mm} / \mathrm{min})$ & $\mathrm{MI}_{30}$ \\
\hline \multirow[t]{8}{*}{ WY (1993) } & Range & 36.60 & 2120 & 0.13 & 0.22 \\
\hline & Minimum & 3.50 & 30 & 0.02 & 0.02 \\
\hline & Maximum & 40.10 & 2150 & 0.15 & 0.24 \\
\hline & Sum & 222.50 & 6693 & - & - \\
\hline & Mean & 19.50 & 608 & 0.07 & 0.09 \\
\hline & Variance & 144.15 & 422,502 & 0.00 & 0.01 \\
\hline & C. V. (\%) & 61.59 & 107 & 65.71 & 83.33 \\
\hline & S. D. & 12.01 & 650 & 0.05 & 0.08 \\
\hline \multirow[t]{8}{*}{ DY (1997) } & Range & 27.40 & 925 & 0.18 & 0.45 \\
\hline & Minimum & 14.80 & 75 & 0.02 & 0.17 \\
\hline & Maximum & 42.20 & 1000 & 0.20 & 0.62 \\
\hline & Sum & 115.60 & 2455 & - & - \\
\hline & Mean & 23.12 & 491 & 0.08 & 0.35 \\
\hline & Variance & 135.73 & 129,605 & 0.01 & 0.03 \\
\hline & C. V. (\%) & 50.39 & 73 & 85.37 & 51.36 \\
\hline & S. D. & 11.65 & 360 & 0.07 & 0.18 \\
\hline \multirow[t]{8}{*}{ NY (1999) } & Range & 29.60 & 1530 & 0.11 & 0.64 \\
\hline & Minimum & 5.10 & 70 & 0.02 & 0.03 \\
\hline & Maximum & 34.70 & 1600 & 0.13 & 0.67 \\
\hline & Sum & 190.50 & 8325 & - & - \\
\hline & Mean & 12.67 & 555 & 0.05 & 0.19 \\
\hline & Variance & 107.73 & 225,943 & 0.00 & 0.02 \\
\hline & C. V. (\%) & 62.26 & 86 & 77.55 & 52.91 \\
\hline & S. D. & 10.38 & 475 & 0.04 & 0.15 \\
\hline
\end{tabular}

Note: C. V. is the abbreviation of the coefficient of variation. RD, D, A.I. and MI30 separately refer to rainfall depth, duration, average intensity and maximal 30-min intensity. 


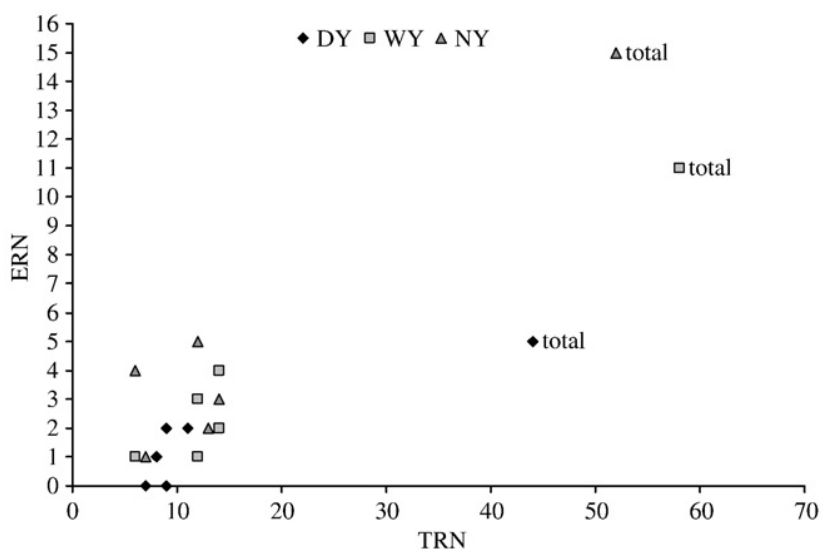

Fig. 2. Rainfall numbers in different months of the three typical years (note: TRN and ERN refer to total rainfall numbers and erosive rainfall numbers, respectively).

those in WY (6.0\% and $1447 \mathrm{tkm}^{-2}$ ) and NY (5.9\% and $\left.1424 \mathrm{tkm}^{-2}\right)$. The lowest runoff ratios and erosion rates were both found in NY.

The runoff ratios and erosion rates varied greatly from May to September in the three typical drought-level years (Fig. 4). Generally, the most severe runoff and soil erosion in DY and NY appeared in July. The least runoff and erosion occurred generally in May and September.

In WY, the highest runoff ratios occurred in June, followed in a decreasing order of August $>$ July $>$ May $>$ September. The erosion rates in the same year experienced a similar order as the runoff ratios, with the highest and lowest ratios also appearing in June and September. In DY, the runoff ratio descended in the order of July $>$ August $>$ May $>$ June $=$ September $=0$, while the erosion rate was in the order of July $>$ May $>$ August $>$ June $=$ September $=0$. In NY, runoff ratio and erosion rate were in the order of July $>$ June $>$ August $>$ May $>$ September and July $>$ June $>$ May $>$ August $>$ September.

\subsubsection{Influence of land use}

The runoff ratios and erosion rates differed between land uses and years (Fig. 5). Generally, water erosion among cropland, alfalfa and scrubland followed a similar trend, i.e., the highest runoff ratios and erosion rates appeared in DY, followed by WY and NY, whereas the
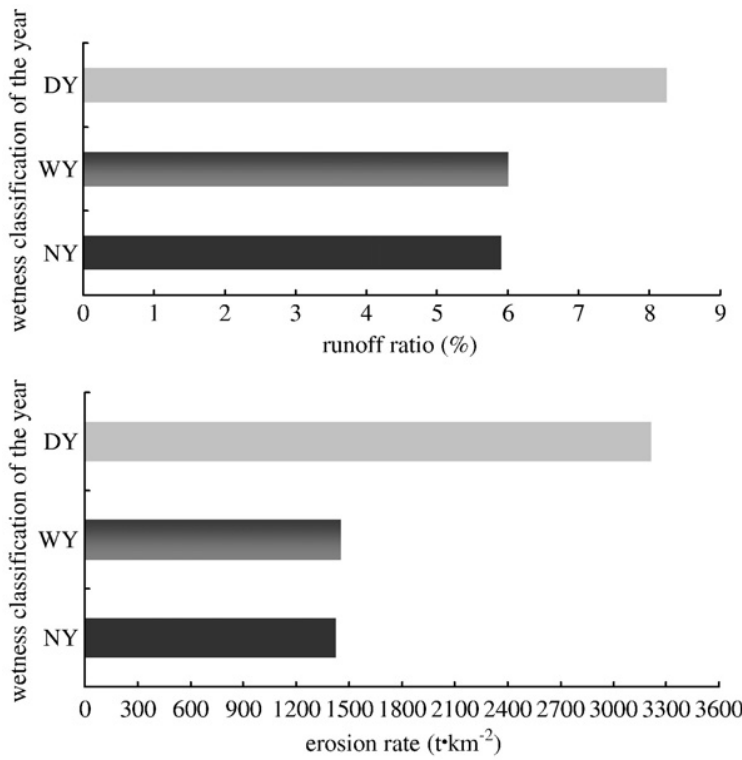

Fig. 3. Mean annual rates of soil and water loss in different drought-level years (note: the mean values were calculated based on the monitored data of the 15 plots).
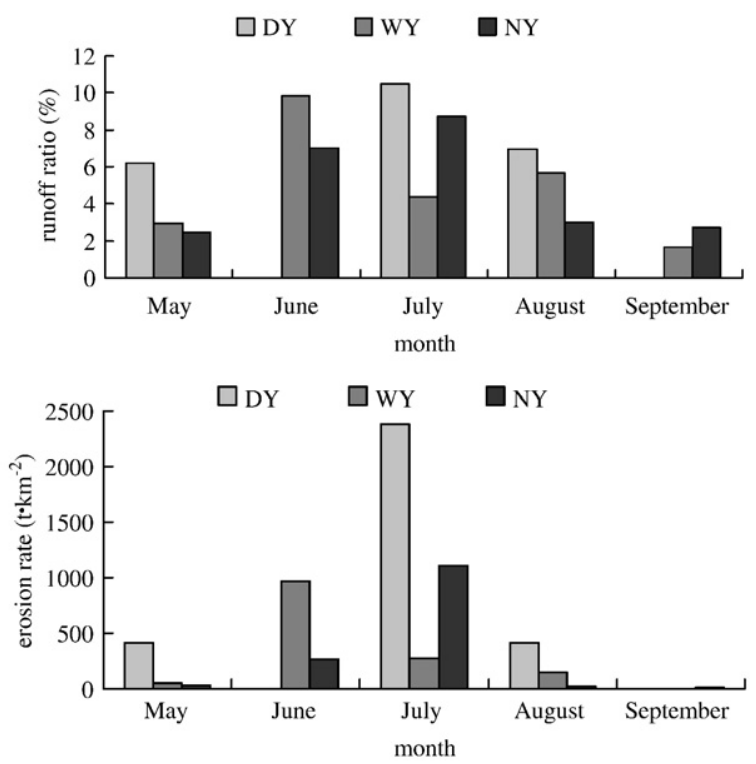

Fig. 4. Monthly runoff ratios and erosion rates in different drought-level years.

related values in woodland and grassland were in the order of $\mathrm{DY}>\mathrm{NY}>\mathrm{WY}$. The runoff ratios under cropland were highest, followed by alfalfa, woodland, grassland and scrubland in all three drought-level years. Similarly, erosion rates in the three typical years were highest in cropland, then alfalfa, grassland, woodland and scrubland. The only difference was between runoff ratios and erosion rates in the grassland and woodland. Runoff ratios were higher in the woodland, while erosion rates were higher in the grassland.

\subsubsection{Water erosion under individual rainfall events}

The runoff ratios of individual events varied significantly among different rainfall events in different years (Fig. 6). Firstly, the number of runoff events differed among these years. Totally, 11, 5 and 15 runoff events were separately monitored in WY, DY and NY. Secondly, the runoff ratios varied among different rainfall events in different drought-level years. In WY, the highest runoff ratio reached $20.6 \%$ (on 10th, June), whereas the lowest ratio was only $1.7 \%$ (on 6th, September). Similarly, the highest and lowest ratios in NY were $21.9 \%$ (on 13th, July) and $1.7 \%$ (on 25th, May), separately. In DY, the
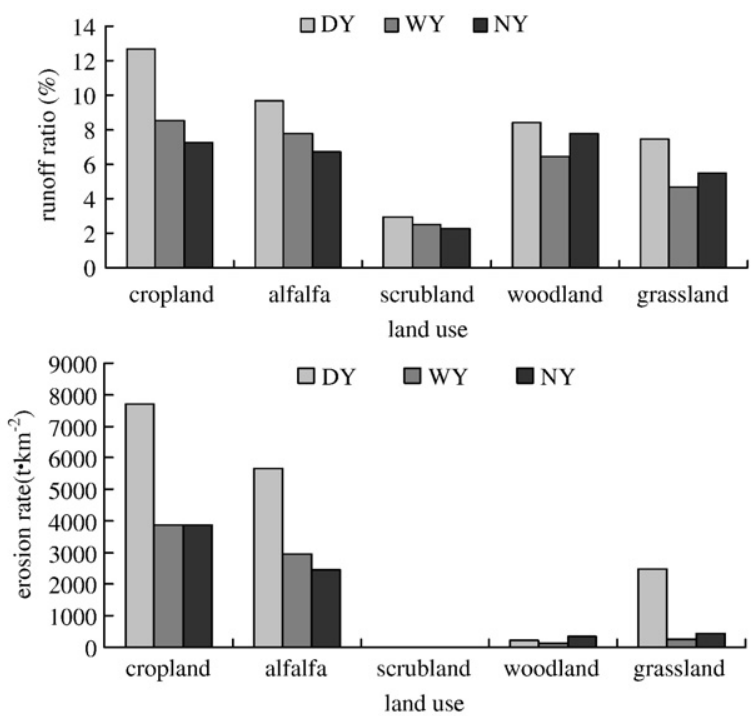

Fig. 5. Annual runoff ratios and erosion rates in different land uses. 

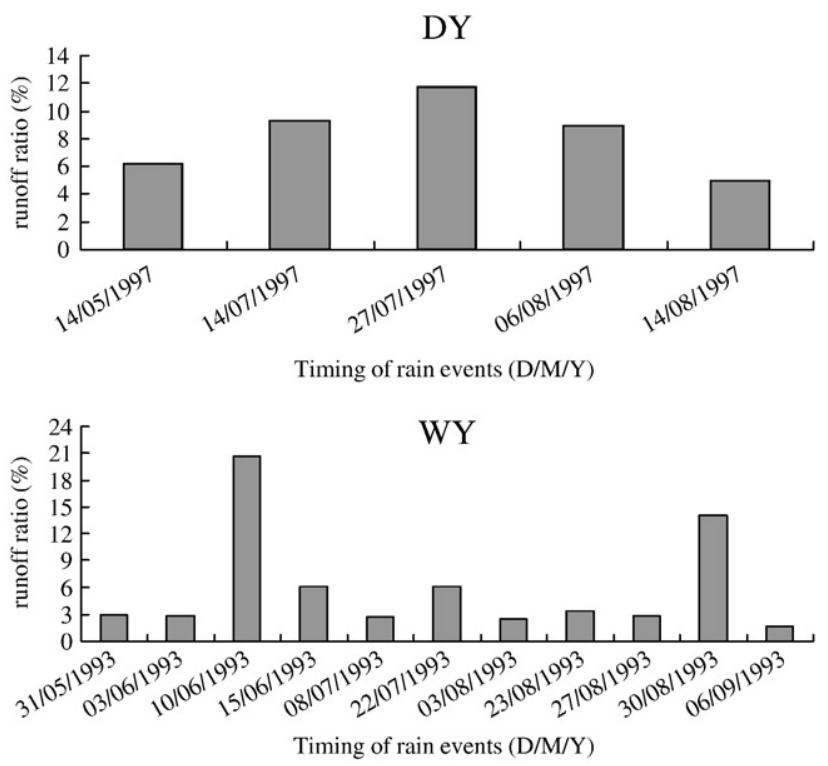

NY

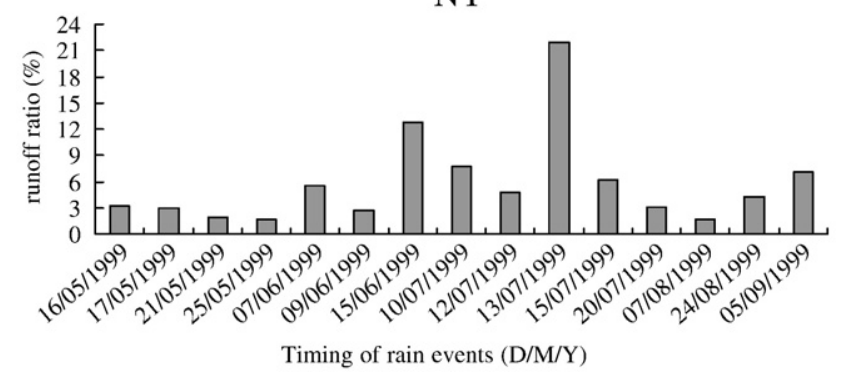

Fig. 6. Mean event runoff ratios in the typical drought-level years (note: runoff ratio was calculated by the mean value of the 15 plots involving the mentioned five land use types; D/M/Y refers to day/month/year).

range between the maximum and minimum was relatively smaller than those in the former two years, with $11.7 \%$ (on 27th, July) and $5.0 \%$ (on 14th, August) respectively.

Generally, the erosion rates varied similarly as the corresponding runoff ratios among different rainfall events (Fig. 7). For example, the maximal and minimum erosion rate in WY and the highest erosion rate in DY occurred simultaneously as the related runoff extremes on June 10 th $\left(927 \mathrm{tkm}^{-2}, 20.6 \%\right)$, September 6th $(0,2.5 \%)$ and July 27 th (1200 t km $\left.{ }^{-2}, 11.7 \%\right)$.

Differences between runoff and erosion, however, also remained. Erosive rain events, which produced surface runoff, did not necessarily produce soil loss, as slight runoff induced by weak rainfall events could not induce erosion in many cases. For example, the rain events, which occurred on August 3 and September 6 in WY, caused runoff ratios of $2.6 \%$ and $1.7 \%$, which were the lowest runoff values in this year (Fig. 6). The corresponding erosion rates, however, were both zero.

\section{Discussions}

\subsection{Response of water erosion to different drought-level years}

In this study, the most interesting discovery was that the highest runoff ratios and erosion rates did not appear in WY, but in DY. Moreover, they were even far higher in DY (1997) than in WY (1993) and NY (1999) (Fig. 3). The result indicates that the annual runoff and soil loss are not necessarily consistent with the annual conditions of total rainfall, which agrees with some other studies (Cantón et al., 2001; Busnelli et al., 2006).
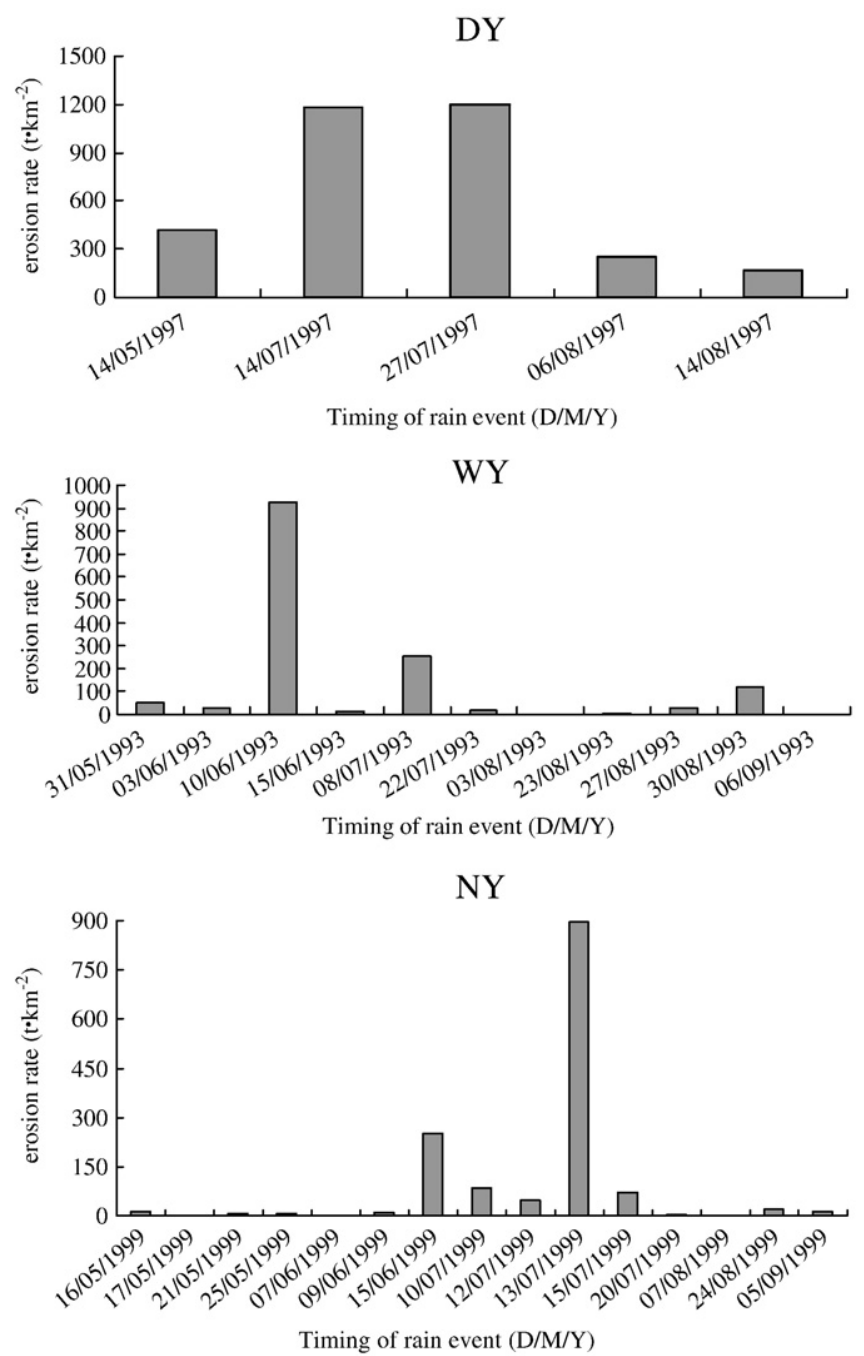

Fig. 7. Mean event erosion rates in the typical drought-level years (note: D/M/Y refers to day/month/year.)

The reasons for this are complex, but mainly due to the high fluctuations and variabilities of temporal rainfall (Hogarth et al., 2004; Nearing et al., 2005; Busnelli et al., 2006). Two aspects however, will be specially addressed here. First, different years represent different drought levels selected by the aridity index defined from the science fields of geography and climatology (Liu, 2006). Due to the relatively lower inter-annual variation of pan evaporation, this aridity index is virtually more affected by rainfall depth in most cases. Rainfall depth, however, is a less important factor determining the degree of water erosion, than other rain properties such as intensity and erosivity. In this study, although rainfall depths and frequencies were in the order of $\mathrm{WY}>\mathrm{NY}>\mathrm{DY}$, mean maximal intensity however, were both highest in DY, far higher than those of NY and WY. This was likely the key reason for the differences in water erosion between the three years. Such findings have been supported by other studies (Jiao et al., 1999; de Lima et al., 2003). Accordingly, more attention should be paid to other important rainfall features which influence water erosion dynamics more than rainfall depth. Second, besides rainfall, changes in runoff affected by rainfall variation will inevitably increase the uncertainties of soil loss caused by erosion dynamics (Hogarth et al., 2004). For example, According to an additional analysis in this study (no data shown here), there is a closely positive correlation between runoff and erosion, which is significant at the 0.05 level. 


\subsection{Effect of temporal variation of rainfall on water erosion}

Our study indicates that water erosion is highly affected by the temporal variation of rainfall in all the three kinds of drought-level years (Fig. 3). The specific changes in rainfall here mainly include three temporal types, i.e., annually, monthly and event variability (Figs. 3, 4, 6 and 7). First, the fluctuations of annual rainfall influence the dynamics of yearly runoff and soil loss rates. As discussed before, rainfall depth is not the most important factor influencing water erosion. Rainfall type, intensity and occurrence all may play significant roles in generating erosion (Dunjó et al., 2004; Apaydin et al., 2006; Busnelli et al., 2006). For example, our study indicates that although the total rainfall depth and number of events were far less in DY than those in WY and NY (Fig. 2), erosion rates in DY were far higher than that in the other years, mainly due to high intensities of the erosive rain events in DY (Table 2 and Fig. 3). The mean annual intensity descended in the order of DY $>W Y>N Y$, which is the same order of the corresponding runoff loss. The major discovery is that types of rainfall are important for determining the severity of soil and water loss. Rainfall events with low intensity and erosivity mostly cannot produce severe erosion, even if they experience high frequencies.

The variability of erosive rainfall events has a significant influence on water erosion (Table 2 and Fig. 2). Only a few of rainfall events were responsible for the majority of annual or seasonal soil loss and sediment yield. For example, the rainfall event, which occurred on 8th, July in WY, produced $64.1 \%$ of the total sediment yield. Similar phenomena also appeared in the other two years (Table 3). Other studies also draw the similar conclusions. For instance, three flooded rainfall events were responsible for more than $50 \%$ of the sedimentation that occurred in the Kamech dam (Tunisia) between the years 1994 and 2002 (Bosch and Hewlett, 1982). Reviewing daily water erosion data in a semiarid Western Mediterranean area, GonzálezHidalgo et al. (2007) found that although erosion varied from year to year, annual amount of soil loss depended on a few daily erosive rainfall events. Torrential flooding was also monitored to be caused by short, but very intense rainfall in NE Spain (Beguería et al., 2008).

\subsection{The role of land use on water erosion dynamics}

Our study indicates that the controlling capacities of different land uses on water erosion differ (Fig. 5). Scrubland had the highest controlling effect and lowest sensitivities on water erosion, followed by grassland, woodland and alfalfa, then cropland. This order is independent from the wetness of the year. Water erosion varied least among years for scrubland than for the other land uses. Rainfall events, which produced runoff, did not necessarily create soil loss and sediment yield, mainly due to the different roles of land uses on controlling water erosion (Table 3 ). We thus strongly recommend that scrubland (such as sea buckthorn) to be the first pioneer plant species for erosion control in the hilly area of the Loess Plateau. Our other studies also confirmed that scrubland is the prior choice for local vegetation restoration (Huang et al., 2005; Wei et al., 2007).

\subsection{Response of water erosion to the dynamics of rainfall and land use}

The temporal changes and fluctuations in rainfall and land use increase the uncertainties and complexities of water erosion (Table 3). It re-conformed that the controlling capacities of various land uses on water erosion differ. Meanwhile, the erosion rates differed between rain events even for the same land use (Figs. 6 and 7; Table 3). Other studies also draw similar results (Zhang et al., 1996; Dunjó et al., 2004). The possible reasons are stressed as follows. First, rainfall variation will influence soil water content, which then influences the dynamics of vegetation development and succession under different land uses, and thus eventually decreases or accelerates erosion (Hou et al., 1996). Secondly, antecedent water content in the

Table 3

Event runoff and erosion rates of each land use in different years.

\begin{tabular}{|c|c|c|c|c|c|c|c|c|c|c|c|c|}
\hline \multirow[t]{2}{*}{ Year } & \multirow{2}{*}{$\begin{array}{l}\text { Rainfall } \\
\text { event }\end{array}$} & \multicolumn{2}{|c|}{ Cropland } & \multicolumn{2}{|c|}{ Alfalfa } & \multicolumn{2}{|c|}{ Scrubland } & \multicolumn{2}{|c|}{ Woodland } & \multicolumn{2}{|c|}{ Grassland } & \multirow{2}{*}{$\begin{array}{l}\text { Percent of ER } \\
(\%)\end{array}$} \\
\hline & & $\mathrm{RR}$ & ER & $\mathrm{RR}$ & ER & $\mathrm{RR}$ & ER & $\mathrm{RR}$ & ER & $\mathrm{RR}$ & ER & \\
\hline \multirow[t]{11}{*}{ WY } & 31-May & 3.5 & 109 & 4.0 & 96 & 2.2 & 2 & 2.5 & 11 & 2.6 & 31 & 3.4 \\
\hline & 3-Jun & 3.7 & 76 & 3.7 & 70 & 1.9 & 0 & 1.9 & 4 & 3.1 & 0 & 2.1 \\
\hline & 10-Jun & 34.6 & 2622 & 32.4 & 1779 & 4.4 & 2 & 20.3 & 69 & 11.4 & 165 & 64.1 \\
\hline & 15-Jun & 8.6 & 39 & 9.5 & 35 & 2.9 & 0 & 3.8 & 0 & 5.7 & 0 & 1.0 \\
\hline & 8-Jul & 3.4 & 503 & 3.4 & 698 & 1.3 & 0 & 2.9 & 16 & 2.3 & 49 & 17.5 \\
\hline & 22-Jul & 8.6 & 33 & 9.7 & 61 & 1.4 & 0 & 6.4 & 1 & 4.2 & 0 & 1.3 \\
\hline & 3-Aug & 3.2 & 0 & 3.2 & 0 & 1.7 & 0 & 2.3 & 0 & 2.4 & 0 & 0.0 \\
\hline & 23-Aug & 2.8 & 16 & 2.2 & 17 & 1.2 & 0 & 7.2 & 1 & 3.3 & 0 & 0.5 \\
\hline & 27-Aug & 3.3 & 77 & 3.3 & 53 & 2.0 & 0 & 2.4 & 6 & 3.1 & 0 & 2.3 \\
\hline & 30-Aug & 20.1 & 402 & 11.8 & 159 & 5.6 & 0 & 20.1 & 16 & 12.5 & 16 & 7.8 \\
\hline & 6-Sep & 2.5 & 0 & 2.3 & 0 & 1.1 & 0 & 1.4 & 0 & 1.2 & 0 & 0.0 \\
\hline \multirow[t]{5}{*}{ DY } & 14-May & 9.6 & 887 & 8.3 & 797 & 1.9 & 0 & 5.7 & 51 & 5.7 & 360 & 13.0 \\
\hline & 14-Jul & 15.1 & 2836 & 7.9 & 1948 & 4.1 & 0 & 11.7 & 63 & 7.9 & 1051 & 36.7 \\
\hline & 27-Jul & 17.3 & 3152 & 16.7 & 2021 & 3.8 & 0 & 10.2 & 55 & 10.5 & 772 & 37.4 \\
\hline & 6-Aug & 14.1 & 476 & 10.0 & 601 & 3.2 & 0 & 9.2 & 17 & 8.4 & 153 & 7.8 \\
\hline & 14-Aug & 7.5 & 360 & 5.5 & 303 & 1.8 & 0 & 5.3 & 24 & 4.9 & 139 & 5.1 \\
\hline \multirow[t]{15}{*}{ NY } & 16-May & 2.8 & 36 & 2.8 & 30 & 1.7 & 0 & 5.6 & 5 & 3.5 & 0 & 1.0 \\
\hline & 17-May & 4.6 & 0 & 4.6 & 0 & 2.0 & 0 & 2.0 & 0 & 2.0 & 0 & 0.0 \\
\hline & 21-May & 2.5 & 17 & 2.4 & 15 & 1.2 & 0 & 1.6 & 0 & 2.4 & 0 & 0.5 \\
\hline & 25-May & 2.1 & 13 & 2.0 & 21 & 1.4 & 0 & 2.3 & 0 & 0.7 & 0 & 0.5 \\
\hline & 7-Jun & 4.8 & 0 & 5.0 & 0 & 2.6 & 0 & 11.2 & 0 & 4.5 & 0 & 0.0 \\
\hline & 9-Jun & 3.3 & 765 & 3.1 & 435 & 1.3 & 0 & 2.9 & 20 & 3.1 & 37 & 17.7 \\
\hline & 15-Jun & 19.0 & 26 & 17.3 & 19 & 3.6 & 0 & 14.7 & 3 & 9.3 & 0 & 0.7 \\
\hline & 10-Jul & 4.5 & 200 & 5.8 & 149 & 3.5 & 3 & 17.0 & 33 & 7.7 & 36 & 5.9 \\
\hline & 12-Jul & 6.0 & 133 & 5.6 & 71 & 1.2 & 1 & 6.0 & 13 & 4.8 & 15 & 3.3 \\
\hline & 13-Jul & 26.1 & 2329 & 22.8 & 1563 & 3.9 & 5 & 27.6 & 224 & 29.1 & 360 & 62.9 \\
\hline & 15-Jul & 8.7 & 240 & 8.0 & 83 & 2.5 & 0 & 7.8 & 35 & 3.8 & 0 & 5.0 \\
\hline & 20-Jul & 4.1 & 16 & 2.9 & 4 & 3.5 & 0 & 2.9 & 0 & 1.8 & 0 & 0.3 \\
\hline & 7-Aug & 2.4 & 56 & 2.3 & 33 & 0.8 & 0 & 1.5 & 9 & 1.7 & 0 & 1.4 \\
\hline & 24-Aug & 4.1 & 0 & 4.3 & 0 & 2.9 & 0 & 6.4 & 0 & 3.9 & 0 & 0.0 \\
\hline & 5-Sep & 10.5 & 30 & 8.7 & 24 & 2.4 & 0 & 8.0 & 4 & 5.7 & 8 & 0.9 \\
\hline
\end{tabular}

Note: RR-runoff rate (unit: \%); ER-erosion rate (unit: $\mathrm{t} \mathrm{km}^{-2}$ ). 
surface soil is proved to be another important factor in determining the threshold of runoff generation (Wei et al., 2006). Thirdly, the seasonality of rainfall was found to partly affect surface crusting and sealing, which are important for water erosion or runoff generation (Singer and Shainberg, 2004). Lastly, rainfall influences the litter decomposition, and litter was proved to be a key factor protecting the surface soil from rainfall and runoff splash (Braud et al., 2001).

\section{Conclusion and suggestion}

In this study, based on consecutive field data in a key rain-fed hilly area of the Loess Plateau, three typical years representing different drought levels (DY, WY and NY) were determined according to an aridity index given by the ratio of potential evaporation and rainfall. Temporal (annual, seasonal and daily) characteristics of rainfall and the rates of runoff and erosion under five implemented land uses in the three typical years were analyzed. The following findings were uncovered. Firstly, the most severe rates of runoff and erosion did not appear in WY but DY. Especially, water erosion in DY was far higher than in WY and NY. This is mainly due to the specific features of rainfall in certain years. Secondly, rain intensity played a more important role in the water erosion processes than other features such as rainfall depth and duration. Erosive events with high rainfall intensities but low frequencies contributed the majority of annual and seasonal water erosion. Thirdly, among the five land use types, scrubland (dominated by sea buckthorn) most effectively reduced the rates of runoff and soil loss, no matter what kind of drought-level year it was.

Our findings are important for water erosion control in this region. Firstly, the severity of water erosion cannot be simply judged by rainfall amount or aridity index. The timing and intensity of precipitation determine the degree and annual fluctuation of surface runoff and soil erosion. Therefore, more special attention should be paid to rainfall types, intensity and timing. Secondly, rare erosive rainfall events always account for a small portion of total rainfall within a certain year but cause most of the damage. Lastly, land use can play a key role in aggravating or weakening the temporal dynamics of water erosion. Wise readjustment, therefore, are absolutely needed.

\section{Acknowledgements}

The Dingxi Institute of Soil and Water Conservation in Gansu province is acknowledged for their valuable assistance on field work and data collection. Our most sincere thanks are also given to Mr. Karl Auerswald and the reviewer who provided constructive comments on improving the manuscript. This research was supported by the National Basic Research Program of China (2009CB421104), the National Natural Science Foundation of China (40925003, 40801041), and the National Advanced Project of the Eleventh Five-year Plan of China (2006BAC01A06).

\section{References}

Apaydin, H., Erpul, G., Bayramin, I., Gabriels, D., 2006. Evaluation of indices for characterizing the distribution and concentration of precipitation: a case for the region of Southeastern Anatolia Project, Turkey. Journal of Hydrology 328 $726-732$.

Baigorria, G.A., Jones, J.W., O'Brien, J.J., 2007. Understanding rainfall spatial variability in southwest USA at different timescales. International Journal of Climatology 27, 749-760.

Beguería, S., Vicente-Serrano, S.M., López-Moreno, J.I., García-Ruiz, J.M., 2008. Annual and seasonal mapping of peak intensity, magnitude and duration of extreme precipitation events across a climatic gradient, northeast Spain. International Journal of Climatology. doi:10.1002/joc. 1808.

Bosch, J.M., Hewlett, J.D., 1982. Areview of catchment experiments to determine the effect of vegetation changes on water yield and evapotranspiration. Journal of Hydrology 55, 3-23.
Braud, I., Vich, A.I.J., Zuluaga, J., 2001. Vegetation influence on runoff and sediment yield in the Andes region: observation and modeling. Journal of Hydrology 254, 124-144.

Busnelli, J., Neder, L.V., Sayago, J.M., 2006. Temporal dynamics of soil erosion and rainfall erosivity as geoindicators of land degradation in northwestern Argentina. Quaternary International 158, 147-161.

Cantón, Y., Domingo, F., Solé-Benet, A., Puigdefábregas, J., 2001. Hydrological and erosion response of a badlands system in semiarid SE Spain. Journal of Hydrology 252, 65-84.

Casalí, J., Gastesi, R., Álvarez-Mozos, J., De Santisteban, L.M., Valle, Del, de Lersundi, J. Giménez, R., Larrañaga, A., Goñi, M., Agirre, U., Campo, M.A., López, J.J., Donézar, M., 2008. Runoff, erosion, and water quality of agricultural watersheds in central Navarre (Spain). Agricultural Water Management 95, 1111-1128.

Chen, L.D., Huang, Z.L., Gong, J., Fu, B.J., Huang, Y.L., 2007a. The effect of land cover/ vegetation on soil water dynamic in the hilly area of the loess plateau, China. Catena 70 (2), 200-208.

Chen, L.D., Wei, W., Fu, B.J., Lü, Y.H., 2007b. Soil and water conservation on the Loess Plateau in China. Review and Perspective Progress in Physical Geography 31 (4), 389-403.

Cook, E.R., Seager, R., Cane, M.A., Stahle, D.W., 2007. North American drought: reconstruction, causes, and consequences. Earth-Science Reviews 81, 93-134.

Davision, P., Hutchins, M.G., Anthony, S.G., Betson, M., Johnson, C., Lord, E.I., 2005. The relationship between potentially erosive storm energy and daily rainfall quantity in England and Wales. Science of the Total Environment 344, 15-25.

de Lima, J.L.M.P., Singh, V.P., Isabel, M., 2003. The influence of storm movement on water erosion: storm direction and velocity effects. Catena 52, 39-56.

Dunjó, G., Pardini, G., Gispert, M., 2004. The role of land use-land cover on runoff generation and sediment yield at a microplot scale, in a small Mediterranean catchment. Journal of Arid Environments 57, 99-116.

Eugenia, G.G., Andreu, V., Rubio, J.L., 2007. Influence of vegetation recovery on water erosion at short and medium-term after experimental fires in a Mediterranean shrubland. Catena 69, 150-160.

FAO-UNESCO. Soil map of the world (1:5000 000). Food and Agriculture Organization of the United Nations, UNESCO, Paris. 1974.

Foley, J.A., DeFries, R., Asner, G.P., et al., 2008. Global consequence of land use. Science 309, 570-574

Fu, B.J., 1989. Soil erosion and its control in the Loess Plateau of China. Soil Use and Management 5, 76-82.

Gafur, A., Jensen, J.R., Borggaard, O.K., Petersen, L., 2003. Runoff and losses of soil and nutrients from small watersheds under shifting cultivation (Jhum) in the Chittagong Hill Tracts of Bangladesh. Journal of Hydrology 274, 30-46.

González-Hidalgo, J.C., Peña-Monné, J.L., de Luis, M., 2007. A review of daily soil erosion in Western Mediterranean areas. Catena 71, 193-199.

Hogarth, W.L., Parlange, J.Y., Rose, C.W., 2004. Soil erosion due to rainfall impact with inflow: an analytical solution with spatial and temporal effects. Journal of Hydrology 295, 140-148.

Hou, X., Bai, G., Cao, Q., 1996. Study on benefits of soil and water conservation of forest and its mechanism in loess hilly region. Research of Soil and Water Conservation 3 (2), 98-103 in Chinese with English Abstract.

Huang, Y.L., Chen, L.D., Fu, B.J., Huang, Z.L., Gong, J., 2005. The wheat yields and wateruse efficiency in the Loess Plateau: straw mulch and irrigation effects. Agricultura Water Management 72 (3), 209-222.

Huang, Z.L., Chen, L.D., Fu, B.J., Wu, X.L., 2004. Erosion reducing effect and its temporal changes of different vegetation types in the semiarid loess hilly area. China Water Resources 20, 38-40 (In Chinese).

Jiao, J., Wang, W., Hao, X., 1999. Precipitation and erosion features of rainstorms in different patterns on the Chinese Loess Plateau. Journal of Arid Land Resources and Environment 13 (1), 34-41 in Chinese with English abstract.

Jin, K., Cornelis, W.M., Gabriels, D., 2008. Soil management effects on runoff and soil loss from field rainfall simulation. Catena 75, 191-199.

Leblance, M.J., Favreau, G., Massuel, S., Tweed, S.O., Loireau, M., Cappelaere, B., 2008 Land clearance and hydrological change in the Sahel: SW Niger. Global and Planetary Change 61, 135-150.

Lal, P., Pimentel, D., 2008. Soil erosion: a carbon sink or source? Science 319, 1040-1041.

Liu, M.C., 2006. Analysis and assessment of climatic dry and wet conditions in Shiyang River Basin. Chinese Journal of Ecology 25 (8), 880-884 In Chinese with English abstract.

Merz, R., Blöschl, G., Parajka, J., 2006. Spatio-temporal variability of event runoff coefficients. Journal of Hydrology 331, 591-604.

Nearing, M.A., Jetten, V., Baffaut, C., Cerdan, O., Couturier, A., Hernandez, M., Le Bissonnais, Y., Nichols, M.H., Nunes, J.P., Renschler, C.S., Souchère, V., van Oost, K. 2005. Modeling response of soil erosion and runoff to changes in precipitation and cover. Catena 61 (2-3), 131-154.

Römkens, M.J.M., Helming, K., Prasad, S.N., 2001. Soil erosion under different rainfall intensities, surface roughness, and soil water regimes. Catena 46, 103-123.

Singer, M.J., Shainberg, A.I., 2004. Mineral soil surface crusts and wind and water erosion. Earth Surface Processes and Landforms 29, 1065-1075.

Trimble, S.W., Crosson, P., 2000. Land use: U.S. soil erosion rates-myth and reality. Science 289, 248-250.

Ulén, B.M., Kalisky, T., 2005. Water erosion and phosphorus problems in an agricultural catchment-need for natural research for implementation of the EU water Framework Directive. Environmental Science \& Policy 8, 477-484.

Wang, X.P., Zhang, Z.S., Zhang, J.G., Li, X.R., Pan, Y.X., Kang, E.S., 2005. Review to researches on desert vegetation influencing soil hydrological processes. Journal of Desert Research 25 (2), 196-201.

Wei, W., Chen, L.D., Fu, B.J., 2009. Effects of rainfall change on water erosion processes in terrestrial ecosystems: a review. Progress in Physical Geography 33 (3), 307-318. 
Wei, W., Chen, L.D., Fu, B.J., Gong, J., 2006. Mechanism of soil and water loss under rainfall and earth surface characteristics in a semiarid loess hilly area. ACTA ECOLOGICA SINICA 26, 3847-3853.

Wei, W., Chen, L.D., Fu, B.J., Huang, Z.L., Wu, D.P., Gui, L.D., 2007. The effect of land use and rainfall regimes on runoff and erosion in the loess hilly area, China. Journal of Hydrology 335, 247-258.

Weltzin, J.F., Loik, M.E., Schwinning, S., Williams, D.G., Fay, P.A., 2003. Assessing the response of terrestrial ecosystems to potential changes in precipitation. Bioscience 53 (10), 941-952.
Western, A.W., Zhou, S.L., Grayson, R.B., McMahon, T.A., Blöschl, G., Wilson, D.J., 2004. Spatial correlation of soil moisture in small catchments and its relationship to dominant spatial hydrological processes. Journal of Hydrology 286, 113-134.

Yair, A., Raz-Yassif, N., 2004. Hydrological processes in a small arid catchment: scale effects of rainfall and slope length. Geomorphology 61, 155-169.

Zhang, X.C., Nearing, M.A., Risse, L.M., Gregaor, K.C., 1996. Evaluation of WEPP runoff and soil loss predictions using natural runoff plot data. Transaction of the ASAE 39, 855-863. 